\title{
Efektivitas Yoga Terhadap Peningkatan Kualitas Hidup ODHA di Bali
}

\author{
I Made Sugata ${ }^{1}$, Putu Emy Suryanti², Made G. Juniartha ${ }^{3}$, Ni Luh Arick Istriyanti ${ }^{4}$ \\ ${ }^{1234}$ Universitas Hindu Negeri I Gusti Bagus Sugriwa Denpasar \\ 1imadesugata65@gmail.com, ${ }^{2}$ emysuryanti@uhnsugriwa.ac.id
}

\begin{abstract}
Abstrak
Tujuan pelaksanaan penelitian ini yaitu mengetahui efektivitas yoga terhadap kualitas hidup Orang dengan HIV/AIDS (ODHA). Penelitian ini adalah penelitian kuantitatif yang menggunakan metode pre-experimental melalui pendekatan one group pretest-posttest design. Sampel dalam penelitian ini adalah ODHA di Provinsi Bali yang aktif mengikuti kegiatan dan bersedia menjadi responden penelitian sejumlah 18 responden. Teknik sampling yang digunakan adalah teknik purposive sampling. Instrumen atau alat ukur dalam penelitian ini adalah kuesioner WHOQOL-HIV BREF yang merupakan instrumen baku dari WHO untuk mendapatkan persepsi kualitas hidup ODHA. Analisis data yang dilakukan adalah analisis univariat dan analisis bivariat. Berdasarkan hasil analisis univariat didapatkan peningkatan nilai kualitas hidup responden setelah diberikan latihan yoga yang ditunjukkan dengan lebih besarnya nilai minimum dan maksimum pada nilai posttest dibandingkan dengan nilai pretest (91-107 > 107-134) serta didukung dengan nilai mean dari hasil posttest yang menunjukkan hasil lebih besar $(116,44)$ dibandingkan dengan nilai mean pretest $(98,72)$. Hasil analisis bivariat menunjukkan perbedaan nilai pretest dan posttest pada skala kualitas hidup ODHA sebesar 0.000 yang menunjukkan perbedaan signifikan antara skor kualitas hidup responden sebelum dan sesudah latihan yoga dan nilai efektivitas latihan yoga terhadap kualitas hidup ODHA adalah sebesar 0,88, yang menunjukkan latihan yoga memiliki efektivitas besar dalam meningkatkan kualitas hidup ODHA di Provinsi Bali.
\end{abstract}

Kata Kunci: Yoga, Kualitas Hidup, Orang dengan HIV/AIDS (ODHA)

\section{Abstract}

The purpose of this research is to know the effectiveness of yoga on the quality of life of people living with HIVIAIDS (PLWHA). This research is a quantitative research that uses a pre-experimental method through a one group pretest-posttest design approach. The sample in this study was PLWHA in Bali Province who actively participated in the activities and were willing to become research respondents with a total of 18 respondents. The sampling technique used is purposive sampling technique. The instrument or measuring instrument in this study is the WHOQOL-HIV BREF questionnaire which is the standard instrument from WHO to obtain perceptions of the quality of life of PLWHA. The data analysis carried out was univariate analysis and bivariate analysis. Based on the results of univariate analysis, it was found that an increase in the quality of life of respondents after being given yoga practice as indicated by the greater minimum and maximum values in the posttest scores compared to the pretest scores (91-107 > 107-134) and supported by the mean value of the posttest results which showed the results greater (116.44) than the mean pretest value (98.72). The results of the bivariate analysis showed the difference in the pretest and posttest scores on the quality of life scale of PLWHA of 0.000 which showed a significant difference between the respondents' quality of life scores before and after yoga practice and the value of the effectiveness of yoga practice on the quality of life of PLWHA was 0.88, which indicates that yoga practice has great effectiveness in improving the quality of life of PLWHA in Bali Province.

Keywords: Yoga, Quality of Life, People Living with HIV/AIDS (PLWHA) 


\section{Pendahuluan}

HIV (Human Immunodeficiency Virus) merupakan suatu virus yang menyerang sistem kekebalan tubuh serta melemahkan kemampuan tubuh untuk memerangi infeksi. Apabila kondisi fisik tanpa perawatan akan muncul gejala yang timbul akibat melemahnya sistem kekebalan tubuh akibat terinfeksi HIV, dimana kondisi ini disebut dengan AIDS (Acquired Immune Deficiency Syndrome). AIDS adalah kumpulan gejala-gejala yang muncul akibat penurunan imunitas tubuh karena terinfeksi HIV. Saat seseorang sudah berada dalam tahap AIDS, maka penyakit ringan pun akan memiliki resiko tinggi terhadap gangguang kesehatan fisik lainnya.

Pada tahun 2015, diperkirakan sebanyak 36,7 juta orang di dunia mengidap infeksi HIV/AIDS. Jumlah infeksi baru untuk infeksi HIV/AIDS diperkirakan sebanyak 2,1 juta orang dan sebanyak 1,1 juta orang di seluruh dunia meninggal akibat infeksi HIV/AIDS. Di Indonesia, jumlah kasus infeksi HIV yang dilaporkan hingga tahun 2014 adalah sebanyak 22.869 orang (13.280 laki-laki dan 9.589 wanita) dengan kasus terbanyak terjadi pada kelompok usia produktif yaitu 25-49 tahun (Ditjen PP \& PL Kemenkes RI, 2014).

HIV/AIDS merupakan salah satu penyakit menular yang jumlah penderitanya semakin bertambah di Indonesia. Bali merupakan salah satu provinsi dengan kasus HIV/AIDS dengan jumlah yang cenderung meningkat di setiap tahunnya. Data dari Kepala Kesekretariatan KPA Bali menyebutkan bahwa di tahun 2019, Bali termasuk dalam lima besar jumlah Orang dengan HIV/AIDS (ODHA) terbanyak setelah Provinsi DKI Jakarta dan Jawa Barat dengan jumlah penderita mencapai 22.034 jiwa dari tahun 1987 sampai dengan Bulan November tahun 2019. Data dari Dinas Kesehatan Provinsi Bali (2019) menunjukkan, Kota Denpasar memiliki jumlah kasus tertinggi, disusul Kabupaten Badung yang menduduki posisi kedua, dan Kabupaten Buleleng yang menduduki posisi ketiga (KPA, 2019).

Vreeman, Scanlon, McHenry, \& Nyandiko (2015) menyatakan bahwa orang dengan HIV/AIDS akan beresiko mengalami permasalahan yang terbagi menjadi tiga hal yaitu masalah fisik akibat dari proses penyakit tersebut, masalah emosional akibat efek dari obat-obatan yang dikonsumsi dan perasaan bersalah, serta masalah psikososial akibat dari stigma lingkungan terhadap orang dengan HIV/AIDS. Masalah dominan yang dihadapi oleh ODHA saat ini adalah stigma dan diskriminasi dari lingkungan sekitar bahkan kelurga terdekatnya sehingga berpengaruh terhadap kesehatan mental dan tingkat stress ODHA, yang nantinya akan berpengaruh terhadap kesehatan fisik yang tidak terkontrol (Vreeman, Scanlon, McHenry, \& Nyandiko, 2015).

Keadaan yang penuh dengan stressor dan kondisi kesehatan fisik yang semakin menurun sangat memungkinkan untuk menurunkan kualitas hidup ODHA. WHO bekerjasama dengan United Nations Programme on HIV/AIDS (UNAIDS) mengusulkan bahwa kualitas hidup harus dijadikan salah satu poin utama dalam pemberian perawatan dan dukungan kepada ODHA (Sun, Wu, Qu, Lu, \& Wang, 2013). Namun kenyataan di Indonesia khususnya di Bali, menunjukkan masih banyak ODHA yang mengalami stress bahkan depresi sehingga tak jarang dari mereka ingin segera mengakhiri hidupnya. Menghadapi kondisi sebagai orang yang positif HIV beresiko untuk mengubah kualitas hidup seseorang secara menyeluruh. Hal ini dibenarkan oleh salah satu ODHA yang menjalankan perawatan kesehatan di salah satu rumah sakit di Bali. ODHA tersebut saat ini berusia 25 tahun dan mengetahui dirinya positif HIV tepatnya 3 tahun yang lalu. Ia mengatakan bahwa :

kehidupan saya mengalami perubahan dramatis dari segala aspek, diusir oleh keluarga, kehilangan pekerjaan, diajuhi teman hingga memiliki keingingan untuk melakukan bunuh diri. Keadaan tersebut membuat kesehatan fisik mengalami penurunan secara drastis (Fjr, 2020) 
Berdasarkan pernyataan di atas, kualitas hidup menjadi aspek penting dalam melakukan evaluasi terhadap pasien dengan infeksi HIV/AIDS. HIV/AIDS bukan hanya dapat menurunkan kesehatan fisik seseorang, melainkan mempengaruhi kualitas kehidupannya dalam segala aspek. Kualitas hidup ODHA memiliki peranan yang penting dalam menjaga setiap aspek kesehatan ODHA. Kondisi psikologis yang tertekan memiliki resiko yang besar untuk mempengaruhi kehidupan ODHA terutama dalam meningkatkan kepatuhannya untuk mengkonsumsi obat. Oleh karena itu sangat penting bagi ODHA untuk melakukan adaptasi terhadap kondisinya, sehingga mampu menyesuaikan diri sebagai cara untuk meningkatkan kualitas hidupnya. Phillips (2007) menyatakan bahwa teknik/terapi complementary dan alternative medicine (CAM) seperti melakukan meditasi dan latihan pengaturan nafas secara teratur memiliki pengaruh signifikan dalam menurunkan tingkat depresi ODHA dan menjaga kesehatan fisik (Phillips, 2007).

Yoga Asana yang merupakan latihan komprehensif terkait dengan pemeliharaan, mampu meningkatkan keselarasan antara pikiran, tubuh, serta keadaan emosional dapat menjadi alternatif dalam membantu ODHA dalam meningkatkan kesehatan fisik dan psikologisnya. Dalam yoga, seseorang akan melakukan latihan yang terdiri dari postur (gerakan tubuh), pranayama (pengaturan nafas), serta bhanda (penekanan nafas pada titik tertentu pada tubuh), seperti menahan nafas di dada, perut, serta diafragma. Yoga telah terbukti menjadi praktik yang mampu menyembuhkan beberapa penyakit dan membantu para pasien HIV di India dalam mengurangi resiko munculnya gejala fisik (Bhagwat $\mathrm{H}$. Garje, 2015).

Dunne dkk (2018) menyatakan dalam penelitiannya bahwa yoga merupakan salah satu teknik yang menjanjikan bagi ODHA untuk mengurangi tingkat stress dan melakukan manajemen terhadap kondisi kesehatan fisik sebagai upaya meningkatkan kualitas hidup ODHA (Dunne et al., 2018). Keberadaan yoga yang sudah menjadi gaya hidup di Bali diharapkan dapat diterima oleh masyarakat khususnya ODHA, sehingga mampu memberikan manfaat khususnya dalam meningkatkan kualitas hidup ODHA di Bali.

\section{Metode}

Penelitian ini merupakan jenis penelitian kuantitatif, dengan menggunakan desain penelitian pre-experimental melalui pendekatan one-group pretest-posttest design. Adapun variabel penelitian ini yaitu : variabel bebas adalah latihan yoga dan variabel terikat adalah kualitas hidup ODHA. Sampel dalam penelitian ini adalah ODHA di Provinsi Bali yang aktif mengikuti kegiatan dan bersedia menjadi responden penelitian sejumlah 18 orang yang didapatkan melalui teknik purposive sampling. Kriteria inklusi yang digunakan dalam penelitian ini adalah : terdiagnosa HIV (+), tidak memiliki riwayat patah tulang, dan sedang dalam prognosis yang baik. Sementara kriteria eksklusi dalam penelitian ini yaitu : penurunan prognosis saat penelitian dan tidak bersedia menjadi responden penelitian.

Semua partisipan akan mendapat perlakuan berupa latihan yoga. Latihan yoga dilaksanakan selama dua bulan dengan total 16 kali pertemuan yang dilaksanakan di Pasraman Natihan Sari, Desa Sibangkaja, Kecamatan Abiansemal, Kabupaten Badung. Latihan yoga dibimbing langsung oleh tiga orang pendamping penelitian yang merupakan instruktur yoga profesional dan bersertifikasi. Selanjutnya akan dilihat efektivitas latihan yoga terhadap kualitas hidup ODHA.

Instrumen yang dipergunakan untuk mengetahui kualitas hidup ODHA ialah kuesioner WHOQOL-HIV BREF yang merupakan instrumen baku dari WHO untuk mendapatkan persepsi kualitas hidup ODHA sebagai responden penelitian. Kuesioner WHOQOL-HIV BREF terbagi dalam 31 pertanyaan yang terdiri dari enam dimensi yakni kesejahteraan dan kesehatan fisik, kesejahteraan psikologis, kemandirian, kesejahteraan sosial, kepuasan lingkungan, kesejahteraan spiritual. Intsrumen ini mempergunakan skala 
likert yang terdiri dari rentang skor 1-5. Semakin tinggi skor yang ditunjukkan oleh responden penelitian, maka semakin tinggi tingkat kualitas hidup yang dimiliki. Semakin rendah nilai yang didapatkan maka tingkat kualitas hidup responden penelitian semakin rendah.

Penelitian ini telah melalui uji kelaikan etik Komisi Etik Penelitian Fakultas Kedokteran Universitas Udayana. Penelitian ini dianalisis secara univariat dan bivariat. Analisis univariat meliputi skor terendah (nilai minimum), skor tertinggi (nilai maksimum), skor rata-rata (mean), serta standar deviasi. Sementara analisis bivariat menggunakan uji wilcoxon untuk mengetahui pengaruh yoga terhadap peningkatan kualitas hidup ODHA. Tingkat kesalahan yang dipergunakan yaitu 5\% dan interval kepercayaan $95 \%$. Tingkat efektivitas dari latihan yoga terhadap perubahan nilai kualitas hidup ODHA akan dihitung menggunakan effect size. Analisis data dilakukan dengan bantuan software SPSS.

\section{Hasil Penelitian}

\section{Karakteristik Responden Penelitian}

Total keseluruhan responden penelitian adalah 18 orang. Berdasarkan jenis kelamin, sebagian besar responden adalah perempuan dengan proporsi responden perempuan 56\%. Berdasarkan karakteristik rentang usia, usia antara 31-40 tahun mendominasi sebagian besar repsonden yaitu sebanyak 8 orang $(44,44 \%)$. Berdasarkan karakteristik tingkat pendidikan, responden lebih banyak memiliki tingkat pendidikan terakhir yaitu SMA/SMK sebesar 50\%. Berdasarkan karakterstik pekerjaan, sebagian besar responden adalah karyawan swasta yaitu sebesar 55,56\%. Berdasarkan karaktersitik status pernikahan, status pernikahan responden adalah belum menikah yaitu sebanyak $55 \%$. Berdasarkan tahun awal terdiagnosa HIV positif, sebagian besar responden terdiagnosa HIV positif pertama kali yaitu pada 5-10 tahun terakhir yaitu sebesar 55,56\%.

\section{Hasil Analisis Univariat}

Analisis univariat dalam penelitian ini mendeskripsikan mengenai skor terendah (nilai minimum), skor tertinggi (nilai maksimum), nilai rata-rata (mean), serta standar deviasi.

\begin{tabular}{|c|c|c|c|c|c|c|c|}
\hline & \multirow{3}{*}{$\begin{array}{c}\mathrm{N} \\
\text { Statistic }\end{array}$} & \multicolumn{4}{|c|}{$\begin{array}{c}\text { Tabel 1. Hasil Analisis Univariat } \\
\text { Descriptive Statistics }\end{array}$} & & \multirow{3}{*}{$\begin{array}{c}\text { Std. } \\
\text { Deviation } \\
\text { Statistic }\end{array}$} \\
\hline & & Minimum & Maximum & Sum & \multicolumn{2}{|c|}{ Mean } & \\
\hline & & Statistic & Statistic & Statistic & Statistic & Std. Error & \\
\hline $\begin{array}{l}\text { Prekualitas } \\
\text { hidup }\end{array}$ & 18 & 91 & 107 & 1777 & 98.72 & .986 & 4.184 \\
\hline $\begin{array}{l}\text { Postkualitas } \\
\text { hidup }\end{array}$ & 18 & 107 & 134 & 2096 & 116.44 & 1.609 & 6.827 \\
\hline $\begin{array}{l}\text { Valid N } \\
\text { (listwise) }\end{array}$ & 18 & & & & & & \\
\hline
\end{tabular}

Berdasarkan tabel hasil analisis di atas, didapatkan bahwa secara keseluruhan terjadi peningkatan nilai kualitas hidup responden setelah mendapatkan intervensi berupa latihan yoga. Hal ini ditunjukkan dengan lebih besarnya nilai minimum dan maksimum pada nilai posttest dibandingkan dengan nilai pretest (91-107 > 107-134). Hal tersebut didukung dengan nilai mean dari hasil posttest yang menunjukkan hasil lebih besar $(116,44)$ setelah mengikuti latihan yoga dibandingkan dengan nilai mean mean pretest yang menunjukkan nilai 98,72. Sehingga dapat disimpulkan bahwa terjadi peningkatan nilai kualitas hidup responden berdasarkan indikator pada kuesioner WHOQOL-HIV BREF setelah responden mendapatkan intervensi berupa latihan yoga. 


\section{Analisis Bivariat}

Uji beda pada skor pretest dan skor posttest digunakan untuk menemukan ada tidaknya perbedaan signifikan antara hasil pretest dibandingkan hasil posttest pada tingkat kualitas hidup ODHA. Penghitungan analisis bivariat dalam penelitian ini menggunakan uji statistik non parametric yaitu uji Wilcoxon Signed-Rank Test. Dari hasil analisis statistik, diperoleh hasil seperti tabel berikut :

Tabel 2. Hasil Analisis Bivariat

Test Statistics ${ }^{\mathrm{a}}$

Post kualitas hidup - pre kualitas hidup

\begin{tabular}{cc}
\hline $\mathrm{Z}$ & $-3.730^{\mathrm{b}}$ \\
\hline $\begin{array}{c}\text { Asymp. Sig. (2- } \\
\text { tailed) }\end{array}$ & .000 \\
\hline
\end{tabular}

Berdasarkan hasil analisis statistik di atas diperoleh perbedaan nilai pretest dan posttest pada skala kualitas hidup ODHA sebesar 0.000. Hasil tersebut lebih kecil dari 0,05 $(0,000<0,05)$, sehingga dapat disimpulkan terdapat perbedaan nilai yang signifikan antara skor kualitas hidup responden sebelum dan sesudah mendapatkan latihan yoga.

\section{Uji Efektivitas Yoga Terhadap Kualitas Hidup ODHA}

Uji efektifitas dilakukan guna mengetahui efektivitas dari intervensi (latihan yoga) yang diberikan terhadap kualitas hidup. Perhitungan nilai efektivitas (effect size) dilakukan dengan perhitungan secara manual dengan rumus, sebagai berikut :

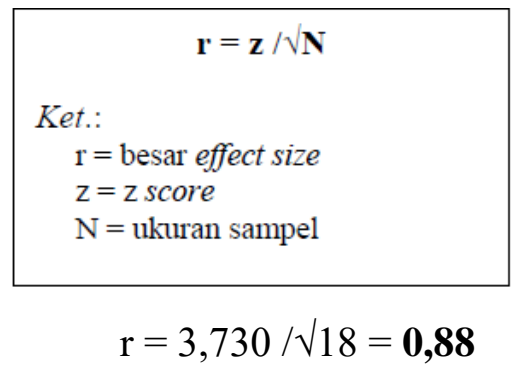

Berdasarkan hasil perhitungan di atas, dapat dilihat bahwa nilai efektivitas latihan yoga terhadap kualitas hidup ODHA adalah sebesar 0,88 , dimana angka tersebut berada di atas $0,80(0,88>0,80)$. Hal ini menunjukkan intervensi berupa latihan yoga memiliki efektivitas yang besar dalam meningkatkan kualitas hidup ODHA di Provinsi Bali.

Latihan yoga yang diberikan dalam penelitian ini merupakan latihan yoga komprehensif yang disesuaikan dengan kondisi kesehatan (baik fisik maupun psikis) ODHA sebagai responden penelitian. Latihan yoga diawali dengan mengambil sikap duduk rileks yang sesuai dengan kenyamanan masing-masing dengan cara meluruskan tiga hal pokok di dalam tubuh yaitu: tulang punggung, leher, serta kepala dengan posisi tegak lurus. Kemudian diikuti dengan penutupan mata dan memusatkan pikiran (konsentrasi), akan tetapi tetap dalam posisi yang menyadari diri (kontemplasi), berikutnya masuk dalam tahap kesadaran secara menyeluruh. Setelah mendapatkan sikap tubuh yang nyaman, dilanjutkan dengan doa. Doa yang dilakukan disesuaikan dengan kepercayaan masingmasing. Doa disini bertujuan agar peserta latihan yoga dihindarkan dari segala hal negatif serta selalu mendapatkan bimbingan dari Tuhan.

Setelah berdoa, dilanjutkan dengan tahap peregangan (Pavanamuktasana) dan pemanasan tubuh (Surya Namaskara). Tahapan ini bermanfaat untuk melemaskan otototot dan mempersiapkan keseluruhan bagian tubuh untuk menerima dan melaksanakan latihan yoga pada tahapan selanjutnya. Setelah melakukan peregangan dan pemanasan, latihan yoga akan memasuki gerakan intinya yaitu asana, pranayama, dan meditasi. 
Gerakan asana terdiri dari berbagai macam gerakan, tetapi pada latihan yoga ini gerakan asana yang diberikan adalah gerakan-gerakan bermanfaat yang disesuaikan dengan kondisi, kebutuhan, dan kemampuan responden penelitian. Tahapan selanjutnya adalah pranayama atau latihan pernapasan. Seperti halnya asana, pranayama juga memiliki berbagai variasi teknik dalam pelaksanaannya. Tahap pranayama sendiri memiliki tujuan untuk menyebarkan prana (energi) ke seluruh tubuh. Tahap pranayama ini bermanfaat untuk meningkatkan sistem kekebalan tubuh terutama responden penelitian yang memiliki sistem kekebalan tubuh yang lemah.

Tahap selanjutnya adalah meditasi (Karuna Samyama). Tahapan meditasi ini bertujuan untuk menciptakan ketenangan dan membangkitkan energi positif dalam tubuh. Sesuai dengan tujuan, tahapan ini bermanfaat untuk meningkatkan persepsi diri terhadap posisinya di dalam kehidupan yang sesuai dengan karakter budaya serta konteks nilai dimana kita hidup terkait dengan tujuan, harapan, standar yang telah ditetapkan, serta fokus seseorang. Serta tahapan akhir dalam latihan yoga dalam penelitian ini adalah rileksasi (Savasana). Tahap rileksasi ini adalah kelanjutan dari tahap meditasi dimana seseorang mencapai keseimbangan mendalam, tubuh serta pikiran mendapatkan ketenangan dan juga kenyamanan. Keseluruhan tahapan dalam latihan yoga komprehensif ini memiliki manfaat sesuai dengan tujuan penelitian yaitu meningkatkan kualitas hidup seseorang terutama ODHA.

HIV/AIDS yang termasuk dalam penyakit kronis dapat memunculkan efek samping yang merupakan bagian dari konsumsi obat-obatan serta infeksi oportunistik. Selain itu, dapat menimbulkan stigma serta diskriminasi bagi para ODHA. Stigma dan diskriminasi pada ODHA besar pengaruhnya terhadap kesejahteraan ODHA secara komprehensif baik dari segi fisik, sisi psikologis, sosial-ekonomi, serta spiritual. Sehingga program perawatan yang ditujukan kepada ODHA tidak hanya berguna bagi usia harapan hidupnya, melainkan bermanfaat bagi peningkatan kualitas hidup ODHA. Kualitas hidup memiliki peran penting dalam mengevaluasi perawatan bagi para ODHA, efek samping penyakit yang ditimbulkan, serta kesejahteraan hidup ODHA (Carsita \& Kusmiran, 2019). Penelitian lain menyebutkan, kualitas hidup diasumsikan sebagai kemampuan bertahan hidup ODHA. ODHA dengan kualitas hidup yang baik diartikan sebagai seseorang yang memiliki kemampuan bertahan hidup yang lebih lama. Perkembangan virus HIV di dalam tubuh ODHA mengakibatkan para ODHA untuk berjuang dengan berbagai masalah dalam kehidupan baik masalah psikososial, masalah kesehatan fisik, dan kesehatan mental dapat mempengaruhi kualitas hidup ODHA baik secara langsung ataupun tidak langsung (Yuliyanti, 2013).

Beberapa hasil penelitian yang mengangkat tema mengenai aspek psikososial memperlihatkan hasil dimana penyakit HIV/AIDS sering dihubungkan dengan permasalahan psikis, yaitu permasalahan mengenai stress maupun depresi. Adanya aktivitas dan kegiatan positif yang dilakukan ODHA dapat mengalihkan dirinya dari pikiran negatif terkait dengan penyakit yang dideritanya, dan kegiatan-kegiatan tersebut mampu meningkatkan kesehatan ODHA secara fisik. Selain itu, aktivitas dan kegiatan positif yang dilakukan ODHA akan mempengaruhi produktivitas ODHA sehingga mampu meningkatkan persepsi positif akan dirinya yang berujung pada peningkatan kualitas hidupnya (Setiyorini, 2015). Latihan yoga dapat menjadi salah satu alternative pilihan aktivitas atau kegiatan positif yang dapat dilakukan oleh ODHA. Latihan yoga selain menjadi aktivitas yang mampu meningkatkan kesehatan fisik, juga mampu memberikan ketenangan secara psikologis bagi para ODHA dalam menghadapi masalah yang dihadapinya. Selain itu, latihan yoga juga mampu meningkatkan aspek spiritual ODHA melalui doa-doa yang dipanjatkan sebelum dan sesudah latihan yoga sesuai dengan kepercayaan masing-masing. Latihan yoga yang diberikan kepada para ODHA pada akhirnya akan membantu ODHA untuk mengatasi permasalahan di segala aspek 
kehidupannya baik permasalahan kesehatan secara fisik dan psikis, permasalahan sosial, serta peningkatan spiritual. Sehingga latihan yoga secara komprehensif dapat membantu meningkatkan kualitas hidup ODHA.

\section{Kesimpulan}

Yoga efektif dalam meningkatkan kualitas hidup ODHA. Hal ini ditunjukkan melalui hasil uji statistik yang diperoleh yaitu nilai perbedaan pretest dan posttest pada nilai kualitas hidup adalah 0.000. Berdasarkan hal tersebut maka dapat disimpulkan terdapat perbedaan signifikan antara kualitas hidup ODHA setelah diberikan latihan yoga. Sementara model yoga yang efektif dalam meningkatkan kualitas hidup ODHA adalah latihan yoga komprehensif yang disesuaikan dengan kondisi kesehatan (baik fisik maupun psikis) ODHA. Latihan yoga komprehensif ini terdiri dari beberapa tahapan utama, yaitu: doa pembuka-peregangan-pemanasan-asana-pranayama-meditasi-rileksasi-doa penutup.

\section{Daftar Pustaka}

Bhagwat H. Garje, P. M. (2015). Role of Yoga Therapy in HIV \& Tuberculosis CoInfection. International Journal Science Reserch and Methodelogy, 1-11.

Carsita, W. N., \& Kusmiran, M. . (2019). Kualitas Hidup ODHA di Kecamatan Bongas. Jurnal Keperawatan Profesional (JKP), 7(2).

Ditjen PP \& PL Kemenkes RI, \& Kementrian Kesehatan RI. (2014). Data Statistik HIV di Indonesia 2014. Kemenkes RI.

Dunne, Balletto, E. \&, Donahue, B. \&, Feulner, M. \&, DeCosta, M. \&, Cruess, J. \&, ... Lori. (2018). The benefits of yoga for people living with HIV/AIDS: A systematic review and meta-analysis. Complementary Therapies in Clinical Practice, 34.

KPA. (2019). Jumlah Penderita HIV/AIDS di Bali. Denpasar.

Phillips, K. D. (2007). Social Support, Coping, and Medication Adherence Among HIV Positive Women with Depression Living in Rural Areas of the Southeastern United States. AIDS PATIENS CARE and STDs, 21, 667-680.

Setiyorini, E. (2015). Gambaran Kualitas Hidup ODHA Yang Menjalani Terapi Antiretroviral (ARV) di Poli Cendana Rsud Ngudi Waluyo Wlingi. Jurnal Ners Dan Kebidanan, 2(1).

Sun, W., Wu, M., Qu, P., Lu, C., \& Wang, L. (2013). Quality of Life of People Living with HIV/AIDS under the New Epidemic Characteristics in China and the Associated Factors. PLoS ONE, 8.

Vreeman, R. C., Scanlon, M. L., McHenry, M. S., \& Nyandiko, W. M. (2015). The physical and psychological effects of HIV infection and its treatment on perinatally HIV-infected children. Journal of the International AIDS Society, 18.

Yuliyanti, A.. (2013). Kualitas Hidup Orang dengan HIV dan AIDS (ODHA) di Kabupaten Jember. Universitas Jember. 